\title{
Facebook Games for English Language Learning: What Student-Teachers Say?
}

\section{Entisar Elsherif ${ }^{1}$}

University of Tripoli

\section{Fatma Dreid}

University of Tripoli

Received: 25-01-2021 Accepted: 07-02-2021 Available Online: 08 -02- 2021

https://doi.org/10.36602/faj/2021.n17.05

\begin{abstract}
This exploratory case study aimed at investigating the studentteachers' views on using Facebook games for language learning. The participants were 48 student-teachers at the EFL Department of the Faculty of Education at a Libyan public university. They were required to play Facebook games for two weeks and then present their experiences through oral presentations and reflective journals. Data were collected through student-teachers' presentations and reflective journals. Data were analyzed qualitatively using a thematic inductive approach. Although few student-teachers had negative views, most of the student-teachers had positive views on using Facebook games for learning. They believed that Facebook games teach players following instructions and provide opportunities for language improvement, especially for vocabulary learning. We expect that our findings would provide teachers and practitioners with ideas for classroom research and encourage researchers to conduct further and more rigorous testing on integrating Facebook games into the EFL classroom.
\end{abstract}

Keywords: Digital Game-Based Learning, EFL Instruction, Social Media Games, Student-Teachers' Perceptions, TEFL Teacher Education.

\footnotetext{
1.e.elsherif@uot.edu.ly
} 


\section{ألعاب الفيسبوك لتعلم اللغة الانجليزية: ماذا يقول الطلاب؟}

فاطمة دريد

جامعة طرابلس
انتصار الشريف

جامعة طرابلس

\section{ملخص البحث}

هدفت هذه الدراسة الى استقصاء اراء طلاب قسم اللغة الانجليزية في كلية التربية عن استخدام ألعاب فيسبوك لتعلم اللغة. وقد شارك في الدراسة 48 طالبة من طالبات قسم اللغة الانجليزية في كلية التربية بأحد الجامعات الليبية. وقد طُلب منهم اللعب بألعاب الفيسبوك لمدة اسبوعين ومن تم تقديم عرض لزملائهم عن التجربة وبعد ذلك كتابة يوميات تحليلية عن التجربة. تم جمع البيانات من خلال مستندات العرض و الكتابة التحليلية التي كتبها الطلبة بعد تحربة اللعب والعرض. تم تحليل البيانات تحليلا نوعيا باستخدام النهج الاستقرائي الموضوعي. أشارت النتائج الى أنه برغم أن هناك عدد قليل من الطلبة الذين كان لديهم أراء سلبية عن استخدام العاب الفيسبوك في تعلم اللغة الانجليزية، الا أن معظم الطلبة كان لديهم اراء ايجابية حول دور العاب الفيسبوك في تعلم اللغة الانجليزية. كان لديهم اعتقاد بأن ألعاب الفيسبوك تعلم اللاعبين اتباع التعليمات وتوفر فرصا لتحسين اللغة، خاصة في تعلم المفردات. نتوقع أن النتائج التي توصلنا اليها ستزود المعلمين بأفكار يمكن تطبيقها في فصولمم والباحثين بأفكار تحثهم على المزيد من الاستقصاء لاجراء اختبارات عن دمج ألعاب الفيسبوك في الفصل الدراسي لتعلم وتعليم اللغة الانجليزية.

الكلمات المفتاحية: التعلم القائم على الألعاب الرقمية، تعلم اللغة الانجليزية كلغة أجنبية،

$$
\text { ألعاب مواقع التواصل الاجتماعي، ألعاب الفيسبوك. }
$$




\section{Introduction}

The basic role of TEFL teacher education programs around the world is to prepare student-teachers to teach English in their countries. Many of these TEFL programs are located in expanding circle countries where English is still considered as a foreign language, among which are the Libyan TEFL teacher education programs. Libyan TEFL teacher education programs mostly focus on language proficiency improvement while student-teachers are being prepared to become EFL teachers. These programs expose student-teachers to language courses to improve their language skills. In this study, we report the findings of our student-teachers' views on using Facebook games for language learning.

\subsection{Research problem}

As teacher educators, we noticed that despite having studied the English language for many years, the student-teachers were still having several language issues. It seemed that our TEFL teacher education program still fell short in raising the student-teachers' confidence for using the English language as many student-teachers' problems were related to their spoken language proficiency. Like many other EFL learners, Libyan student-teachers were hesitant to speak, unable to communicate or give presentations, lacked or misused vocabulary, demotivated by being forced to talk about uninteresting topics along with other negative factors that affected their spoken language proficiency (Abdallaha, 2018; Abrar, et al. 2016; Dew, Kultsum \& Armadi, 2017; Pathan, Aldersi, \& Asout, 2014). If student-teachers who are being prepared to become teachers of the English language are having issues in their speaking skills, this is problematic. Through speaking, they not only express their ideas and communicate with others, but also give instructions, explain concepts, show how to pronounce words, and explain ideas and other language learning components. Consequently, we had to consider ideas that would motivate them to participate in the Listening \& 
Speaking courses more effectively and improve their language proficiency.

The question that we raised was: how can we encourage the Libyan student-teachers to use the language to communicate and give effective presentations in a friendly and encouraging environment? The answer to our question came in "gameplay." Gameplay has always been perceived as an activity in which players find joy. Thus, as teacher-educators, we have never perceived gameplay as a meaningful learning activity. The idea of using gameplay came after Elsherif was engaged in gameplay by playing Facebook games and had seen the advantages of playing games as a graduate student and a teacher-educator herself when she was a $\mathrm{Ph} . \mathrm{D}$. student at Indiana University of Pennsylvania. Playing Facebook games and writing reflections in Gian Pagnucci's class made Elsherif believe in the effectiveness of games in facilitating language learning. Playing Facebook games made her realize that games "offer students a hypothetical environment in which they can explore alternative decisions without the risk of failure" (Martinson \& Chu, 2008, p. 478). In games, students combine "[t]hought and action" into "purposeful behavior to accomplish a goal" (p. 478). Playing games teaches language learners "not to strategize, to consider alternatives, and to think flexibly" (p. 478).

As teacher-scholars who try to make their classes studentcentered, give the student-teachers more chances for communication, and as believers in game-based learning, we decided to use Facebook Games to make the learning and presentation process exciting and to encourage the student-teachers to speak. If we can tie language learning "to popular forms of gaming in a way that doesn't inhibit its enjoyment, that's a winning situation" both for the student-teachers and for us as educators (Godwin-Jones, 2014, p. 9). Thus, the purpose of the study discussed in this paper was to explore Libyan studentteachers' views towards using Facebook games in learning the English language. 


\subsection{Research questions.}

As mentioned earlier, the main aim of this study was to explore the student-teachers' perspectives on implementing Facebook games for language learning. In parallel with this aim, we raised the following research questions that grounded this study:

1. What are the Libyan EFL student-teachers' views on the Facebook games they played?

2. What are the Libyan EFL student-teachers' perspectives on using Facebook games for learning?

\subsection{Research objectives.}

Following a socio-constructivist and learner-centered approaches to achieve student-teachers' effective presentation performance and collaboration in a friendly environment, in this study, we attempted to contribute to the scarce research on implementing Facebook games in the language classroom in the Libyan context and aimed to achieve the following objectives:

1. Investigate the Libyan EFL student-teachers' views on the Facebook games they played.

2. Investigate the Libyan EFL student-teachers' perspectives on using Facebook games for learning.

\subsection{Research terms.}

Games are defined as a "form of play" (Byrne, 1995) or "activities" (Hadfield, 2000) that are directed by rules and goals and have "an element of fun" (p. 4). Games can be divided into traditional games and digital games. Since the focus of this study is on Facebook games, our focus is on digital games. Digital games are those games that are played on computers, cellphones, or the kinds of commercial games that are played on "platforms like the PlayStation 2, the GameCube, the Xbox, and the handheld Game Boy" (Gee, 2007, p. 7). Digital games can be divided into educational games that are 
purposefully designed to provide opportunities for planned learning activities through gameplay and games that are designed for entertainment but provide chances of incidental learning because of players' interactions with the game and with each other (Gee, 2007; Godwin-Jones, 2014).

Social-network games, also known as social media games or social games, are digital games that are "designed to be played with friends" (Rossi, 2009, p. 1) on social platforms such as Facebook. In this study, we focused on Facebook games as they are the most "evident and wide spread" games (Rossi, 2009, p. 1). Facebook games are varied and ranged as they are designed for different age groups and to connect friends with each other, which give educators the chance to use them for games-based learning.

\subsection{Related studies.}

Mastering speaking skills is an essential part of English language learning (Byrne, 1995). Spoken language proficiency is a significant element in learning to communicate effectively. One of the ways that are used to increase language learners' motivation to communicate in English and encourage them to speak is gameplay. Games are considered as promising means for educational purposes because games provide a context rich environment and various learning experiences that highlight a strong connection to real-life knowledge and experiences (Wu, Chen, \& Huang, 2014).

In games-based learning process, as detailed in the Model of Game-Based Learning, learning happens as learners interact while playing a game (Garris, Ahlers, \& Driskell, 2002). Since learning is conceptualized as a multidimensional construct that involves learning skills, cognitive learning outcomes, declarative and strategic knowledge, and attitudes, gameplay interactions provide language learners with authentic chances for learning while interacting with games and with their peers. 
While some language teachers and researchers remain skeptical regarding the use of games in the language classroom (Foster, Mishra \& Kohler 2010), recent research shows that EFL teachers used games to encourage English language learners to use the English language effectively (Aldabbus, 2008; Guvendir \& Gezgin, 2015; Ho, Thien, Thi, \& Vy, 2020; Nguyen \& Pham, 2018). Games are effective for language learning as they create motivation and increase learners' achievement, give learners the chance to gain new instructions, aid critical thinking ability, lower students' stress and reduce anxiety, improve listening skills, generate fluency, develop learners' speaking skills, enhance vocabulary, encourage EFL learners to practice grammar, provide great opportunities for real communication, improve learners' discussion skills, bring real-life simulations, have some spirit of competitiveness, and encourage cooperation (Dewi, Kultsum, \& Armadi, 2017; Guvendir \& Gezgin, 2015; Ho et. al., 2020; Nguyen \& Pham, 2018).

Research on the use of social-network games is getting more attention than before. Even though they are "designed for entertainment, not education" (Godwin-Jones, 2014, p. 11), researchers found that social-network games increase students' motivation and positively influence their school performance, which leads to fulfilling their educational goals, improved target language production, and extensive practice in the four skills (Gee, 2007; Guvendir \& Gezgin, 2015; Ho et. al., 2020; Mubasalat, 2012; Urrutia \& Vega, 2010).

When it comes to the Libyan context, research on games is limited and mostly investigated the use of the educational games in the language classroom (Aldabbus, 2008; Owen, Samad, Razali, \& Noordin, 2019), which indicated that there was a gap in the available research on the student-teachers' views on using social media games in ELT. The Libyan researchers' findings supported the findings of other researchers in that games improve learners' performance, 
enhance vocabulary, raise their confidence, and that using games make learning more fun (Aldabbus, 2008; Owen, et.al., 2019).

As spoken proficiency is essential to student-teachers and to give them more opportunities to give presentations in English confidently, we gave the student-teachers the chance to play social media games. As future teachers, we believed that our studentteachers should understand the significance of games-based instruction in the EFL classroom through Facebook games. As teacher-educators, we provided them with an opportunity to understand that learners' active engagement and motivation can be achieved through game-based instruction, not just through regular classroom interactions (Tham \& Tham, 2012). Thus, the current study seeks to contribute to the existing literature by exploring the studentteachers' perspectives on integrating social media games-based language learning activities.

\section{Methodology}

The main aim of this qualitative exploratory case study was to explore the student-teachers' perspectives on implementing Facebook games for language learning. We chose the qualitative exploratory case study approach as our research questions determined that our focus is not quantifiable data and cannot be understood through measuring. Through qualitative research, we seek to understand how our student-teachers "interpret their experiences, how they construct their worlds, and what meaning they attribute to their experience" (Merriam, 2009, p. 14) while they were playing Facebook games. Case study was chosen because of its features that include being particularistic, descriptive, and heuristic. Another reason for choosing case study as our methodology is that it gives us the chance to have a "holistic description and explanation" (Merriam, 2009, p. 43).

\subsection{Context of the study.}

The study was conducted at the TEFL teacher education program at the Faculty of Education at University of Tripoli. The 
basic aim of this TEFL program is to prepare Libyan student-teachers for the challenges of teaching the English language in Libyan schools. Thus, the student-teachers take several compulsory and elective courses in which they improve their language proficiency and learn how to teach.

\subsection{The participants.}

The participants were forty-eight student-teachers who were taking the Advanced Listening \& Speaking course as two groups in two semesters: Fall 2018 and Spring 2019. All the participants were females. To ensure their privacy and anonymity, research ethics procedures were taken into account. Most importantly, studentteachers were assured that their participation in the study was voluntary and their real names will not be used. Any information that might reveal their real identities were hidden. Thus, all names that will be mentioned are pseudonyms. In addition, to keep their identities and views hidden, their reflections are acknowledged with a letter and a number, such as R1. Finally, to make guessing the real names of the cohorts who participated in the study difficult, we decided to use two school years that are different from the real ones: 2018 and 2019.

\subsection{The Facebook games project.}

The Facebook games project was in five phases. In Phase 1, the student-teachers were asked to form groups and then choose a game from the following list of Facebook games (in alphabetical order): City Ville, Criminal Case, Farm Ville, Hay Day, Hidden Chronicles, Royal Story, Lucky Supermarket, Secret Passages, The Secret Society, The Smurf's Village, Threads of Mystery, Village Life, Words of Wonder, and Zoo World; considering the diversity of Facebook games that are available for players. With a critical and selective approach, we chose the games that seemed to be appropriate for different learners' ages and language levels (Harris, 2006; MacKenty, 2006). In Phase 2, the student-teachers began playing the games in class and then continued playing at home for two weeks. In class, they were 
guided to play as groups. Then, in Phase 3, the student-teachers prepared their presentations in which they had to provide a summary about their games, describe how they played them, and specify the kind of knowledge they have gained while playing in details. Later, in Phase 4, the student-teachers gave their presentations. Finally, in Phase 5, the student-teachers wrote reflections about the games, their performance, and the whole experience of playing the games and presenting about them as EFL learners and their views and evaluations of the games as future EFL teachers.

\subsection{Data collection and analysis.}

Data were collected through student-teachers' presentations and reflective journals as they include student-teachers' views and selfassessment. We chose written reflections over using interviews because self-reflection process facilitates reflexivity and helps writers to examine their own beliefs, experiences, and subjectivities with a critical eye (Cohen, Manion, \& Morrison, 2007). Reflective journals are also considered as an efficient way to obtain information about the student-teachers' feelings (Cohen, Manion, \& Morrison, 2007).

Data collection procedures began after the student teachers' submitted all their course requirements. When classes were over, student-teachers' presentations and reflective journals were gathered as data. Data analysis was mainly qualitative. A thematic inductive approach was used to code and analyze the data after our line-by-line reading and memoing (Coffey \& Atkinson, 1996). In the following section, we provide a brief discussion of the findings in thematic order.

\section{Results}

Two research questions were raised to explore the Libyan EFL student-teachers' views on using Facebook games for language learning. Our data showed that the student-teachers chose and played seven games from the games that were suggested to them. Data analysis indicated that the student-teachers had positive and negative 
views on the use of Facebook games for language learning. In the following sections, we present the findings of the study in the order of the study's research questions.

\subsection{Student-teachers' views on the Facebook games they played.}

Most of the student-teachers confessed that they had never played Facebook games before they were assigned to them as one of the course requirements. They also revealed that even though they were new to Facebook games, they were able to achieve the game goals and feel satisfaction. Lara's words summarized some of her peers' views:

In general, I do not like Facebook games. So, at first, I was not excited about the game we chose as a group. But, later, I found that it was fine and then enjoyable. This is the first time I have played games on FB, so everything was new to me and sometimes difficult. However, following the instructions and getting the tasks done made me feel satisfied as I achieved what was required (R30, 2019).

The Facebook games that the student-teachers chose to play were three adventure games, two mystery games, and two social simulation games. The games were Criminal Case, Farm Ville, Hay Day, Lucky Supermarket, Secret Passages, The Secret Society, and Village Ville. In most of these games, the student-teachers had to read texts, hear some people talking or giving instructions or orders, and understand clues to solve problems or achieve goals. They also play various roles depending on the genre of the game. So, student-teachers had to use the English language to understand the games' requirements and achieve their goals as well as to communicate as players.

Sixteen student-teachers played the role of the detective in Criminal Case. All student-teachers thought that the game was "interesting to players who like murder mysteries." They believed that it was "beneficial as it has lots of words [learners] might not know." 
However, two of them believed that the game is "not suitable for children as it includes blood and dead people sceneries" (R5, 2019).

Twelve student teachers played the roles of farmers in FarmVille and Hay Day games. The student-teachers thought that the farming games were "amazing and interesting," "easy to follow," and teach "how to be responsible farmer" and "have easy instructions" (R9 \& R15, 2019). However, some of them thought that they might be "boring for those who are not interested in farming," or those who "don't like repeating the same work over and over" (R6, R12, \& R16, 2019).

Four student-teachers played the role of the manager in the social simulation game Lucky Supermarket. All student-teachers found the game "interesting" as they had to solve customer problems and meet their satisfaction. They believed the game was beneficial as it "has new words" (R40, 2019).

Eight student-teachers played hidden object mystery games, the Secret Society and the Secret Passages. All student-teachers stated that the games are "exciting to those who like mysteries," "can be useful because they include a lot of unknown words," "challenge your mind in different ways," and that "time plays a big role in the game, so [players] learn to manage time and be patient" (R19, R24, R33 \& $\mathrm{R} 45,2019)$.

Eight student-teachers played world-building social simulation game, Village Life, which is no longer available for players now. Student-teachers thought that the game was "fun as [they] help [their] villagers get married and raise families and form tribes" and "develops creativity by decorating the villages and making them look beautiful" (R2 \& R38, 2019).

As can be seen from the previous descriptions, there is an overall satisfaction, even though some students found some of the games "boring" because of the repetition component. It is also noticeable that the detective and hidden objects games attracted the 
student-teachers more than the other games and motivated them for learning.

\subsection{Student-teachers' views on implementing Facebook games for learning.}

Data analysis revealed that the student-teachers had positive and negative views on the use of Facebook games for language learning. The student-teachers in favor of using Facebook games thought playing Facebook games was "beneficial to English language learners" and admitted that they were planning to use Facebook games "wisely" (Emy, 2019) as future EFL teachers. In the following sections, we discuss the student-teachers' positive and negative views about using Facebook games.

\subsubsection{Student-teachers' positive views about using Facebook games.}

Most of the student-teachers had positive views about using Facebook games for language learning. As indicated in one of the participants' reflections, student-teachers thought that "the idea of using Facebook games is fascinating, as the learners will be exposed to many learning opportunities" (R47, 2019). In the following sections, we discuss the four positive themes that are a result of data's thematic analysis.

Facebook games as a source of motivation. Data showed that most student-teachers' believed that games captivate and engage learners. They thought that Facebook games develop new knowledge and skills, enable learners to undertake impossible tasks, and experience situations that might include scenarios that are not transferable to real-world experiences. Thus, they believed that playing games motivates the learners as players to achieve the goals and finish the tasks, which leads to learning. As one of the studentteachers puts it: 
when you play for fun and achieve the game goals, you feel that you need to achieve more and it motivates you to do more of the tasks of the game (R6, 2019).

In this excerpt, the student-teacher explains how achieving one task of the game motivates players to achieve more. Another student-teacher discussed how playing made her learn new words and understand the instructions, which motivated her to play more to learn more:

I do not play games at all. So, this was a new experience for me. When I began playing so I can meet the assignment requirements; I was playing and questioning our professor's decision in including this. I was asking myself why we are wasting our time by doing this? But then, things changed. I started to enjoy playing because I began to realize that the more I played, the more I was using my English to understand. I also noticed that I was learning new words. Criminal Case gave me the chance to be motivated to learn. (R10, 2018)

Facebook games develop students' creativity and problemsolving skills. Student-teachers viewed the games' content, narration, design, and some of the tasks as a form of creativity and imagination development and problem-solving skills developer for the players. Some of the student-teachers explained that some games' content is presented in the form of narrative style and storytelling and therefore encourages creativity. Safa explained:

In the Village Life game, I felt that I was contributing to creating the story of the game. I was the narrator as well as the creator of the whole story of the village. This made me feel happy.

Another student-teacher explained:

playing the game improved my imagination. I felt that I was able to imagine more scenes. I felt like I was creating new worlds. (R7, 2018)

Talia added: 
I think that we gained the skill of creativity as we play. When we think about ways of dividing the farm to grow more crops, we need to be creative so that we have all we need in the farm while it looks beautiful and not jammed. (R25, 2018)

Student-teachers also mentioned the use of "money" to buy goods and achieve their goals as great opportunities for learning spending and problem-solving strategies. As explained by one of the student-teachers:

In our game, Lucky Supermarket, we had to build a supermarket and sell our goods to customers. We had to spend our money to gain more money. We also learned how to solve any problem that might face us while trying to achieve our goals as players and satisfy the customers to receive the awards of the game. (R3, 2019)

Her other peers also declared that games taught them how to spend their money and use their resources and how to get the tools and things they need by collaborating with other players.

Facebook games as a source of language development. Nearly most of the student-teachers thought that Facebook games can improve learners' language proficiency. All of those who had positive views on Facebook games believed that games teach how to follow instructions, improve reading comprehension, and a great source for vocabulary learning.

All student teachers believed that the games they played taught them how to follow instructions. This is clearly stated in the following script:

Before playing the game. I did not understand what it was about. then I followed the instructions. The knowledge I gained from the game is how to read the instructions very well and apply them. (R3, 2019) 
Student teachers also mentioned reading comprehension as one of the positive sides of playing Facebook games that leads to language improvement. One of the student-teachers summarized the idea in the following text:

Finally, it helped us to learn reading skills for example: skimming, when we read the instructions. We do not need to read all; we had already gotten the idea. All of these things are coming by practicing.

Finally, the most mentioned advantage is vocabulary learning. All the student-teachers admitted that they have learned lots of words by playing Facebook games. Some gave examples, such as "victims, detective, investigation, travel in time, conspiracy, manage the market, goods, serve customers, cash" and other words and phrases. Lama explained:

from this game I got to learn several new words, such as: harvest, sprinkler, bushel, redeem, plow. Also, I learned some information about agriculture, such as how to plow, plant, and harvest.

\subsubsection{Student-teachers' negative views about using Facebook games.}

Ten student teachers had negative views on using Facebook games for learning. Five of the student-teachers regarded using Facebook games in the English classroom as a waste of time. They believed that Facebook games are time consuming, boring, and therefore, discouraging. Student-teachers believed that Facebook games can be "boring" as they played the same tasks over and over repeatedly. Moreover, in some games, some student-teachers faced difficulties in getting the tasks done. So, they thought learners will be discouraged to play games in which they cannot achieve their goals. Besides, a few of the ten student-teachers believed that Facebook games are not "suitable" for learners with high levels of language proficiency as they might not find new information, which might 
demotivate them to play. They also believed that Facebook games are not "appropriate" for all ages as they believed that some of the games are not appropriate for young learners

\section{Discussion}

In the current study, It is sought to examine the student-teachers' perspectives on using Facebook games for learning. The Findings show that, after collaborating as groups, playing Facebook games together, and giving presentations as a team, the student-teachers' attitudes towards games-based learning changed.

Some student-teachers' initial assumption was that having gameplay as one of the course requirements was a waste of time and had negative attitudes towards playing Facebook games, especially that most of them admitted that they have never played the games before. After playing Facebook games, the student-teachers reported positive views about the affordances of Facebook games and how games enhance their language proficiency.

There was an overall satisfaction about gameplay among the student-teachers, even though they had never played the games before. They thought that playing Facebook games was beneficial as the games gave them knowledge about detective work, farming, store management, mysteries, and raising families. They also believed that the games (1) teach responsibility such as being responsible of farming and store management, (2) teach time management as some games require players to finish tasks on time, (3) challenge players to think critically, and (4) develop creativity. These findings are in line with the findings of Gee, 2007, Ho et. al., 2020, Mokhtari, MohammadKazemi, \& Kamkar (2016) and other researchers.

Facebook games also enhanced student-teachers' language learning motivation. Facebook games motivated players to achieve more and learn more, which showed how games lead to intrinsic motivation. Intrinsic motivation "serves as the initial engine to generate learning and later functions as a driving force that helps to 
sustain the long journey of acquiring a foreign language" (Cheng \& Dörnyei, 2007, p. 153). Without the "sufficient motivation", language learners cannot "achieve a working knowledge" and will not be able to "persist long enough to attain any really useful language" (Dörnyei, 2010, p. 74). Thus, Facebook games can be used in the EFL classroom or as a homework activity to motivate the learners to improve their language proficiency (Ebrahimzadeh \& Alvi, 2017).

Another advantage that our data revealed is incidental learning. Jameel Ahmad (2011) defined incidental learning as "the process of learning something without the intention of doing so" (p. 71). With this meaning in mind, we noticed that nearly all student-teachers admitted learning new vocabulary. Incidental vocabulary learning is learning from context that emerge engaging learners in extensive reading, conversations, listening to stories, music, films, or radio, watching television or movies, and/or playing games (Letchumanan et. al, 2015). Our data confirm other researchers claim in that games help learners "acquire vocabulary in a fun-filled and nonthreatening environment" (Letchumanan et. al, 2015, p. 737).

Finally, Language teachers' beliefs about teaching and classroom management differ from one teacher to another, especially when it comes to using games (Al-Issa, 2011). There is a belief that games are "a waste of time," which makes some teachers "prefer not to use them in classroom" as they only consider "one element that is fun" (Khudhair, 2016, p. 70). Likewise, some student-teachers questioned the value of using Facebook games for language learning. Even after playing the games and realizing what they have learned from the games, they still mentioned the disadvantages of using games.

Even though we chose the games that seemed to be appropriate for different learners' ages and language levels with a critical and selective approach, the student-teachers reported some of the disadvantages that Stojkovic and Jerotijevic (2011, p. 941) reported in 
that games (1) might stray the learners away "from the basic purpose of the game-play activity" that might lead to "playing too much and the lack of learning," (2) familiar or boring games might not get students be "equally involved," and (3) some students might "find games unnecessary and childish." Therefore, as one of the studentteachers advised, teachers should be critical and selective and choose the games wisely taking into account their learners' ages and language proficiency levels, the purposes of using games, and time allocated for gameplay, especially when choosing social media games for learning (Ho, Thien, An, \& Vy, 2020).

\section{Conclusion and Recommendations}

In this paper, the study that examined the Libyan studentteachers' perspectives on using Facebook games for learning was discussed. After collaborating as groups, playing Facebook games together, and giving presentations as a team, the student-teachers' attitudes towards games changed. A close examination of the findings indicate that Libyan student-teachers recognize the value of gamebased learning as learners and as future teachers.

This explorative case study was designed to gain a further understanding of the student-teachers' views on using Facebook games for language learning. We expect that our findings would provide teachers and practitioners with ideas for classroom research and encourage researchers to conduct further and more rigorous testing on integrating Facebook games into the EFL classroom. So, it can be regarded as an important step towards understanding the significance and the impact of the employment of games-based learning in teacher education programs. The study also signifies the possibility of implementing games at the university level and using them in the classroom.

This study has a few limitations. Basically, the student-teachers' presentations and self-report in the reflective essays might face a potential problem of validity because all student-teachers knew that 
they were participating in a research project as well as their comprehension of the tasks and willingness to provide honest answers (Ary, Jacobs, Sorensen, \& Razavieh, 2010).

Even though this study can be seen as a small-scale study, as we only explored the views of 48 student-teachers, it opens up wide doors for other teacher-educators to investigate the impact of games on student-teachers' academic performances and language proficiency improvement as well as on using social media games for EFL learning and teaching. The outcomes of this research may help TEFL researchers, teachers, and practitioners to evaluate the effectiveness of Facebook games and other social media games in facilitating language proficiency development, critical thinking, and problem-solving skills. More research is needed to examine the benefits of using Facebook games and other social media games in TEFL.

In the future research, as this study was merely qualitative, quantitative, and experimental approaches are needed to examine the perspectives of a wider range of Libyan student-teachers on the use of Facebook games for language learning improvement and their effects of EFL learners' spoken language proficiency and presentation performance. 


\section{References}

Abdallaha, N. S. (2018). Speaking difficulties that face Libyan EFL university students: A case study of first-year students at the Faculty of Arts and Science, Human and Community Studies Journal, 8, 1-17.

Abrar, M., Failasofah, F., Fajaryani, N., \& Masbirorotni, M. (2016). EFL Student Teachers' Speaking Anxiety: the Case in One English Teacher Education Program. Indonesian Journal of English Education, 3(1), 60-75.

Ahmad, J. (2011). Intentional vs. incidental vocabulary learning. Interdisciplinary Journal of Contemporary Research in Business, 3(5), 67-75.

Aldabbus, S. (2008). An Investigation into the Impact of Language Games on Classroom Interaction and Pupil Learning in Libyan EFL Primary Classrooms. A thesis submitted for the degree of Doctor of Philosophy, School of Education, Communication, and Language Sciences, Newcastle University. Retrieved from: https://core.ac.uk/download/pdf/40056248.pdf

Al-Issa, A. S. M. (2011). ELT games and teacher beliefs: The use of games in teacher education in Oman. Reflections on English Language Teaching, 8(1), 35-52.

Ary, D., Jacobs, L. C., Sorensen, C. \& Razvieh, A. (2010). Introduction to research in education. Australia: Wadsworth Cengage Learning.

Byrne, D. (1995). Teaching Oral English. Harlow: Longman Group UK.

Cheng, H. F., \& Dörnyei, Z. (2007). The use of motivational strategies in language instruction: The case of EFL teaching in Taiwan. Innovation in Language Learning and Teaching, 1(1), 153-174.

Cohen, L., Manion, L., \& Morrison, K. (2007). Research methods in education (6th ed.). Abingdon: Routledge 
Coffy, A. J., \& Atkinson, P. A. (1996). Making sense of qualitative data: Complementary research strategies. Thousand Oaks, CA: SAGE.

Dewi, R. S., Kultsum, U. \& Armadi, A. (2017). Using communicative games in improving students' speaking skills. English Language Teaching, 10(1), 63 -71.

Dörnyei, Z. (2010). Researching motivation: From integrativeness to the ideal L2 self. In S. Hunston \& D. Oakey (Eds.), Introducing applied linguistics: Concepts and skills (pp. 74-83). London: Routledge.

Ebrahimzadeh \& Alvi (2017). The effect of digital video games on EFL students' language learning motivation. Teaching English with Technology, 17(2), 87-112.

Foster, A., Mishra, P., \& Koehler, M. J. (2012). Digital game analysis: Using the technological pedagogical content knowledge framework to determine the affordances of a game for learning. In M. Khine (Ed.), Learning to Play: Exploring the Future of Education with Video Games. New York, NY: Peter Lang Publications

Garris, R., Ahlers, R., and Driskell, J.E. (2002). Games, motivation, and learning: A research and practice model. Simulation and Gaming, 33(4), 441-467.

Gee, J. P. (2007). Good video games + Good learning: Collected essays on video games, learning and literacy. New York: Peter Lang.

Godwin-Jones, R. (2014). Games in language learning: Opportunities and challenges. Language Learning and Technology, 18(2). 9 19.

Guvendir, E. \& Gengiz, D. M. (2015). The effect of a Facebook game that requires English vocabulary knowledge on students' English vocabulary development. Journal of Educational Sciences Research, 5(1), 41 - 55.

Hadfield, J. (2000). Intermediate Communication Games. Harlow: Longman. 
Harris, C. (2006). Meet the New School Board: Board games are back - and they're exactly what your curriculum needs. School Library Journal, 55(1), 24-26.

Ho, P. P. V., Thien, N. M., Thi, M. \& Vy, H. N. N. (2020). The effect of using games on EFL students' speaking performances. International Journal of English Linguistics, 10(1), 183 - 193.

Khudhair, N. K. (2016). Investigating Iraqi EFL Intermediate School Teachers' Perceptions toward Using Language Games for Learning English. Al-Ustath, 219(1), 69-90.

Letchumanan, K., Tan, B. H., Paramasivam, S., Sabariah, M. R. and Muthusamy, P. (2015). Incidental learning of vocabulary through computer-based and paper-based games by secondary school ESL learners. Pertanika J. Soc. Sci. \& Hum. 23 (3): 725 -740 .

MacKenty, B. (2006). All Play and No Work. School Library Journal, 52(2), 46-48.

Martinson, B. \& Chu, S. (2008). Impact of learning style on achievement when using course content delivered via a gamebased learning object. In Ferdig, R. E. (ed.). Handbook of research on effective electronic gaming in education (pp. 478 488). Pennsylvania: IGI Global.

Merriam, S. B. (2009). Qualitative research: A guide to design and implementation. Revised and expanded from qualitative research and case study application in education. San Francisco, CA: Jossy-Bass.

Mokhtari, MohammadKazemi, \& Kamkar (2016). Computer games and their impact on creativity of primary level students in Tehran. Independent Journal of Management \& Production, 7(3), 926-936.

Mubaslat, M. M. (2012). The effect of using educational games on the students' achievement in English language for the primary stage. Retrieved from: https://files.eric.ed.gov/fulltext/ED529467.pdf

Nguyen, T. M. A., \& Pham, V. P. H. (2018). Improving EFL Students' Speaking Performance by Using Games in the Classroom (pp. 128-137). Conference Proceedings, ISBN: 978-604-922-659-5. 
Owen, E. A., Samad, A. A., Razali, A. B., \& Noordin, N. (2019). Enhancing Libyan students' English speaking performance through language game and information gap activities. Problems of Education in the $21^{\text {st }}$ Century,77(1), 110-125.

Pathan, M. M., Aldersi, Z. E., \& Alsout, E. A. (2014). Speaking in their Language: An Overview of Major Difficulties Faced by the Libyan EFL Learners in Speaking Skill. International Journal of English Language \& Translation Studies, 96-105.

Rossi L. (2009), Playing your network: gaming in social network sites. Proceedings of DiGRA http://www.digra.org/wpcontent/uploads/digital-library/09287.20599.pdf (retrieved 14.10.2020).

Stojkovic, M. K. \& Jerotijevic, D. M. (2011). Reasons for using or avoiding games in as EFL classroom. 1st International Conference on Foreign Language Teaching and Applied Linguistics, 940-947.

Tham, L., \& Tham, R. (2012). Is game-based learning an effective instructional strategy to engage students in higher education in Singapore? A pilot study. Journal of the Research Center for Educational Technology (RCET), 8(1), 2-10.

Urrutia, R., \& Vega, T. (2010). Encouraging Teenagers to Improve Speaking Skills through Games in a Colombian Public School. Boston.

Wu, C. Chen, G. \& Huang, C. (2014). Using digital games for genuine communication in EFL classrooms. Educational Technology Research and Development, 62(2), 209-226. 